The origin of these varieties which are found in stable form in close-fertilized species (and which exist potentially in crossfertilized species) is a matter of great interest, both theoretically and practically. The adherents of the mutation theory will see in them a confirmation of their views. The rest of us are compelled to admit that, thus far, their origin is obscure.

In the light of the facts cited, the question whether a given crop is cross-fertilized or close-fertilized becomes a matter of prime importance, as different methods of procedure are required in the two cases. Dr. Hopkins states that clover plants selected in a manner analogous to that described for timothy, did not reproduce true to seed, but that the plants grown from the seed of a single plant represented all the forms observable in the original field of clover. This is what Mendel's law leads us to expect, if clover is cross-fertilized, a matter which has recently been called in question. It is easily seen that we have here a list. of important problems for plant physiologists, in determining definitely what crops do and what crops do not cross-fertilize. There is likewise a broad and promising field of work in securing in a stable form superior strains of all ordinary crops to which these methods have not already been applied. The amount of improvement possible represents the difference between the mixture of all strains and the best components of the mixture.

\title{
BREEDING FOR AND ON THE RANGE.
}

By Prof. J. H. Shepperd, Fargo, N. D.

The food and shelter which are commonly given to range stock differ widely from the environment surrounding animals grown upon small mixed farms in the East. Practical ranchmen believe that stock which would be entirely adapted to the best productive results under their conditions should be of a different type and have several changes in characteristics. Range grown stock at maturity and at the time of marketing are considerably smaller than stock of the same age and breed which have been reared under mixed farm conditions.

The supply of food on the range is less uniform than that which is available upon small farms and there is probably more of a cessation of growth as a consequence, in range stock, during the winter season than there is with similar animals which are cared for upon small farms. This difference accounts to a considerable extent for the reduction in size of range grown stock, even when bred from a range reared ancestry.

Ranchmen who have cattle and horses usually provide much less shelter, even for their storm enclosures, which are used during severe weather, than do the breeders living upon mixed farms.

I remember visiting a place on the North Dakota range which is called Mule Springs. I was told that the name was given to the 
place by reason of the success of two old worn out mules which were turned loose upon the prairie in the fall of the year to live as long as the weather conditions would allow and meet their fate without the knowledge of their heartless owner. The venerable beasts found a spring which remained open and supplied them with water during the entire winter. By grazing and sheltering as best they could in the vicinity, they managed to live through the winter and in the spring greeted their unworthy owner in their wonted way when he brought back his herd to his summer quarters.

It is an open question among ranchmen who are producing cattle and other stock for the market, whether it pays to feed them hay or corn fodder except during severe storms. They say that when stock is given hay, in limited quantity, they depend upon it for subsistence and will not put forth sufficient effort to secure range grass enough to supplement their supply of hay. They report that in many instances their stock is so indifferent about grazing when they have had a fraction of the amount of hay that will carry them satisfactorily, that they will not take the trouble to gather prairie grass and as a consequence come out in a much poorer condition in the spring than if they had received no hay whatever.

More activity is necessary in stock for the western range and greater courage is required of them. Cattle men who are familiar with range conditions commonly agree that Hereford stock have an advantage over other breeds, in that they do not so readily give up when attempting to secure a livelihood from range grass in the winter. It is entirely probable that a more active and nervous temperament on the part of the range steers and sheep is required than it would be well to have in those produced on small and mixed farms. A nervous animal is usually avoided by the small farmer, as such a one is not likely to lay on flesh rapidly nor with any paying degree of economy. A disposition to be persistent in the matter of foraging is certainly a good and commendable point in range stock. Range animals develop more slowly than farm stock and probably have a longer total growth period.

Ranchmen are not interested in "baby .beef" as they desire to manufacture roughage in the form of uncut grass, either green or cured, into beef, which necessitates slow development. One of the questions discussed regularly by ranchmen is the advisability of shipping steers to market at three years old or at four years old.

Comparatively few of the cattle, horses, and sheep bred on the ranges are grain fed before marketing and in consequence the things demanded of a bunch of stock by the grain feeder receive little consideration at the hands of the ranchmen, except in so far as they meet the requirements of animals which are to be marketed in a grass fat condition.

Range sheep need closer fleeces than those produced on small farms as the snow drives into an open fleece badly during storms and a sheep with a wet skin commonly catches cold, fails to gain in weight, and, when taken collectively, a considerable proportion of them contract disease, remain puny for a time, and die. The ranch- 
man seems to require a different proportion of wool to mutton than is presented by most of the breeds of sheep produced and, as a consequence, many of them follow the pernicious practice of crossbreeding.

Ranch owners lose vast sums of money annually by not having a pure breed of sheep that will produce the type which they approximate by cross-breeding, although a form which will still better serve their purpose could certainly be produced by intelligent, coöperative breeding. The range country needs a breed of sheep which will give them the added productive value which comes from a breed of animals selected, bred and adapted to their specific purpose.

Ranchmen can scarcely be expected alone to bear the burden of building up a new breed as it is a matter which requires concerted and coöperative action and its remunerative results are likely to accrue more largely to the advantage of another generation than to the present one. Mankind is not prone to look favorably upon enterprises which cannot yield much in the form of material results until twenty-five years have elapsed and, for that reason, it would seem improbable that anything will be accomplished without state and government aid and coöperation. The men who are engaged in the ranching business are alert as observers and are commonly bright, active fellows but as breeders few of them look ten years ahead. They are a class of stock men addicted to cross-breeding and thus largely throw away the advantage which they could secure from heredity. They give as a reason for cross-breeding that no existing breed of sheep answers their purpose. Ranchmen who keep sheep will tell you almost to a man that they are forced to cross breed their stock because no existing breed is adapted to their agricultural conditions.

Many of the points which will best adapt range sheep to their environment are not settled beyond dispute by ranchmen, hence much value will accrue from an investigation which will record the actual results and adaptation resulting from particular methods of breeding.

A plan is now under consideration whereby a number of North Dakota ranchmen are to breed sheep in coöperation with the United States Department of Agriculture and the North Dakota Experiment Station. By having a large number of lambs produced each season and by making a careful record of their type and condition covering such points as hardiness, grade of wool, weight of fleeces, vigor, prolificacy, quality, feeding capacity, and the grade of mutton produced, an improved strain cannot fail to be the outcome of a few to several years of breeding. Such a breeding experiment will enable the coöperators to measure the prepotency of individual animals with an accuracy which cannot fail to produce results. The get of one sire can be fed out in comparison with those from another male and the fattened beasts followed to the block and through the slaughter house so that no mistake can occur relative to the capacity of their offsprings as producers of valuable products in an economic way.

If a number of breeders located upon the range will make a study of their environment and of the facilities of the average ranch owner, 
and mold a type of stock which will meet the requirements of the range, they will add to the quality and value of the animals produced in a vast belt of country.

Breeding animals shipped in from eastern farms seem to suffer a decided shock from their change of environment, notwithstanding, the fact that they are given much better conditions of food and shelter than the herd or flock they are designed to head. There is usually a stunting effect upon them which they outgrow to some extent in the course of a year. During the first twelve months on the range, the average breeding animal which has been shipped from a small stock farm to the range, gradually loses flesh and vitality. The more careful range breeders do not count on using sires much during the first year after they are shipped west, but wait until the stock becomes what they call acclimated.

Imagine the fate of a yearling bull which has never lived without a nurse cow, if he is bid off at a high figure by a breeder from the Great Plains country and taken west to subsist on plain buffalo grass and water henceforth. The change in environment and in the food supply is so great that the results are likely to be disastrous. It is the common belief of the stockmen that animals in high condition of flesh and finish should be maintained in that condition during the breeding season. Breeders generally agree that female animals should gradually improve in condition from the time of impregnation until the young are born, which I believe really means that they are more likely to be vigorous and thrifty when they are improving in condition than they are when they stand still or fall off in flesh.

If that principle is well founded, a change from a well kept eastern farm to the range must bring a result which breeders seek to avoid, and from that standpoint it would seem to me that breeding stock reared upon small farms in the east or central west are not well adapted for use upon the ranges. Stock for the ranger must show no flaw in constitution and no lack of vigor, even if these points must be obtained at the expense of size, thickness of flesh and smoothness.

I have observed that range cattle do not obtain permanent teeth as early as do "show stock" which have been kept in a high condition. On the other hand; I have observed that range sheep and cattle suffer from loss of teeth or from bad teeth earlier than do cattle or sheep produced under small farm conditions. Ranchmen say that buffalo grass slips through the teeth of the sheep and wears the shanks of them until they become so weak that they break off close to the gums. They also say that feeding from short grass has a tendency to make cattle strike more or less sand and grit which results in their wearing their teeth down much more rapidly than eastern stock commonly do. While it is scarcely probable that the most ingenious breeder can modify the teeth of his animal to any considerable extent, it is a matter which he must consider, as it means that his breeding stock will have a shorter period of usefulness than is common for animals grown under farm conditions.

The breeding of grasses and forage plants for range conditions, to be carried out successfully, as it seems to me, must be done in the 
range country. Personally, I have a considerable degree of faith in the domestication of some of the native range grasses, but whatever improvement awaits the future breeders of grasses and forage plants for the range, there can be little doubt of better results coming from breeding operations which are carried on under range environment than from those which are conducted at arm's length in the more humid districts of the country. The combination of grass varieties and climate which results in the range grass curing into excellent standing winter food for stock is in itself a feature of untold value and should be retained in the grasses bred up for that district, even if it is kept at the expense of the quantity which it is possible to produce.

I am of the opinion that the idea entertained by some breeders that the east and central west should produce the breeding stock, or at least the sires which are used upon the range, is a mistaken plan of procedure and I further believe that whatever is produced and molded by breeding must meet with the greatest degree of success when it is brought forth and developed under the conditions of soil, forage, climate and handling, which must be the lot of its descendants.

\section{PLANT AND ANIMAL INTRODUCTION.}

\section{By David G. Fairchild, U. S. Department of Agriculture.}

Plant and animal breeding is becoming a manufacturing process. Two of the most important things in the manufacture of any product are the material and the tools, and to place various exotic animals and plants in the breeders' hands is to furnish him with these materials and tools with which to work. It is therefore the question of securing these which I wish especially to emphasize in this paper.

The American Indians, like the South African Kaffirs, were a race of hunters and fishers, and the hazard of the chase led them away from the surer profits of plant and animal cultivation just as the uncertainty of the tipping system misleads a host of hotel waiters or the chances of prospecting demoralize all mining camps. This is a reason why, with all the wonderful resources of wild fruits, forage plants, and grains, the first European settlers on this continent found most of the wild fruits uncultivated and the other economic plants culturally untouched.

The neglected resources of American forests and plains has comparatively recently attracted the special attention of breeders, and there is perhaps a tendency to encourage the development of strictly American races.

The success of certain American sorts of plants and animals seems to support the idea that advantage is to be gained by the amelioration of only indigenous types.

The world of plants and animals is too varied and the climatic conditions of the earth are too uniform to make such a view broaci 